\title{
Resources for Studying Abraham Lincoln and the American Civil War around the World
}

\author{
Daniel W. STOWELL*
}

As director and editor of the Papers of Abraham Lincoln and as director of the Center for Digital Initiatives at the Abraham Lincoln Presidential Library and Museum in Springfield, Illinois, it has been my pleasure to make materials for the study of his life and times more accessible through the Internet. The Papers of Abraham Lincoln grew out of the Lincoln Legal Papers, which began in 1985. In 2001, the project expanded beyond Lincoln's law practice to cover his entire life and career. Our goal is to locate, digitize, transcribe, annotate, and publish freely online all documents written by or to Abraham Lincoln during his entire lifetime.

As part of this commitment, we have created several web publications that may be of interest to readers of this Journal. For the study of Abraham Lincoln's life and words, three of our web publications are most important. First, The Lincoln Log: A Daily Chronology of the Life of Abraham Lincoln (www.thelincolnlog.org) offers a calendar format and digest of Lincoln's actions on any day of his life about which we have information. Researchers worldwide can learn what Lincoln was doing and with whom he was interacting on almost every day of his Presidency and many dates in the 1850 s and before. For example, a researcher can learn about Lincoln's 12 March 1862 meeting with Joseph Heco (Hikozo Hamada) at the Executive Mansion and see the source for that information. The

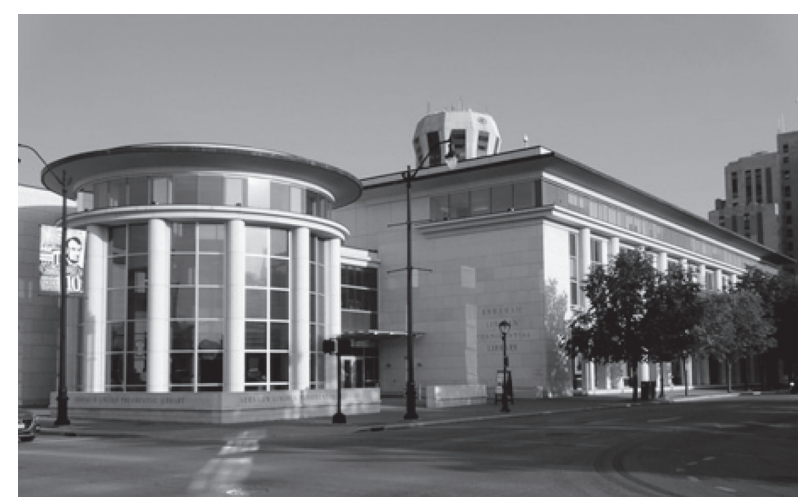

* Daniel W. Stowell is director and editor of the Papers of Abraham Lincoln, Springfield, Illinois. 
Lincoln $\log$ is designed to be a digest of information and not an exhaustive source. It is helpful, however, in understanding where Lincoln was and what he was doing on specific dates.

Second, researchers can view all surviving documentation of Abraham Lincoln's law practice in The Law Practice of Abraham Lincoln, Second Edition (www.lawpracticeofabrahamlincoln.org). This database brings together images of more than 98,000 documents from Lincoln's quarter-century legal career. Although the documents are not transcribed, editors extracted more than 2 million pieces of metadata, including all of the people involved in the cases, legal issues, courts, dates, subjects, and a summary of more than 5,100 cases and more than 500 non-litigation legal activities. For example, ten cases have some connection to the California Gold Rush of 1849. At least two cases involved women who sued for divorce because their husbands deserted them to go to California. Others relate to the failure of partnerships to travel to California to mine gold. Researchers can learn much about both Abraham Lincoln's career and the history of nineteenth-century America from these legal sources.

Third, researchers familiar with The Collected Works of Abraham Lincoln, 8 vols. (1953), available online at http://quod.lib.umich.edu///lincoln/, should also consult the images of documents made available by the Papers of Abraham Lincoln at The Papers of Abraham Lincoln: Images from the National Archives and Library of Congress (http://papersofabrahamlincoln. dataformat.com). This web publication provides early access to images of more than 76,000 documents from our research at the National Archives and Library of Congress. Although the documents are not transcribed, researchers can search by date, title, or collection. Here, researchers can view a translation of a 22 January 1862 letter from the five-year-old Tongzhi Emperor of China to Abraham Lincoln. At the time, China was ruled by Tongzhi's mother Empress Dowager Cixi and Empress Dowager Ci'an. Included in one translation of the letter is a fascinating commentary by the translator on the significance of a phrase stating that the Emperor received a commission from God to rule (or "to soothe and bridle") all the world. The translator recommends that no further notice be taken of the objectionable expression and emphasizes instead other phrases implying equality between the Emperor and the President and between China and the United States.

To demonstrate the global significance of Abraham Lincoln's life and legacy, the Center for Digital Initiatives at the Abraham Lincoln Presidential Library and Museum created Abraham Lincoln: Citizen of the World (www. citizenlincoln.org). This web publication combines two types of global sources on Abraham Lincoln's life and legacy, both plotted on a world map. It includes more than 450 letters of condolence from around the world sent in 
1865. As word of Lincoln's assassination spread around the world in April and May 1865, spontaneous meetings of citizens, labor unions, religious organizations, Masonic lodges, antislavery societies, and local officials gave voice to their grief in letters of condolence and tribute. The resulting letters and resolutions were addressed to President Andrew Johnson, Secretary of State William H. Seward, diplomatic officials, Mary Lincoln and her children, the United States Congress, the American people, or any combination of these individuals and groups.

The tributes were heartfelt and often eloquent. One eulogy in a French newspaper insisted that "Lincoln represented the cause of democracy in the largest and the most universal acceptation of the word. That cause is our cause, as much as it is that of the United States." The citizens of a village in Sicily declared, "Abraham Lincoln was not yours only-he was also ours, because he was a brother whose great mind and fearless conscience guided people to union, and courageously uprooted slavery." A group of French medical students insisted, "In President Lincoln, we weep for a fellow citizen; for no country is shut up now." The citizens of Abruzzo, Italy, proclaimed, "Your history is the same as ours. From Lincoln and Seward to Garibaldi and Mazzini, the tradition of the great struggle between good and evil, liberty and slavery, civilization and barbarism, national autonomy and the rule of foreign despots, has ever been the same." The Portuguese governor of Macau expressed his "profound grief" and reflected that "this fatal occurrence will serve however to render still more grateful and cher-

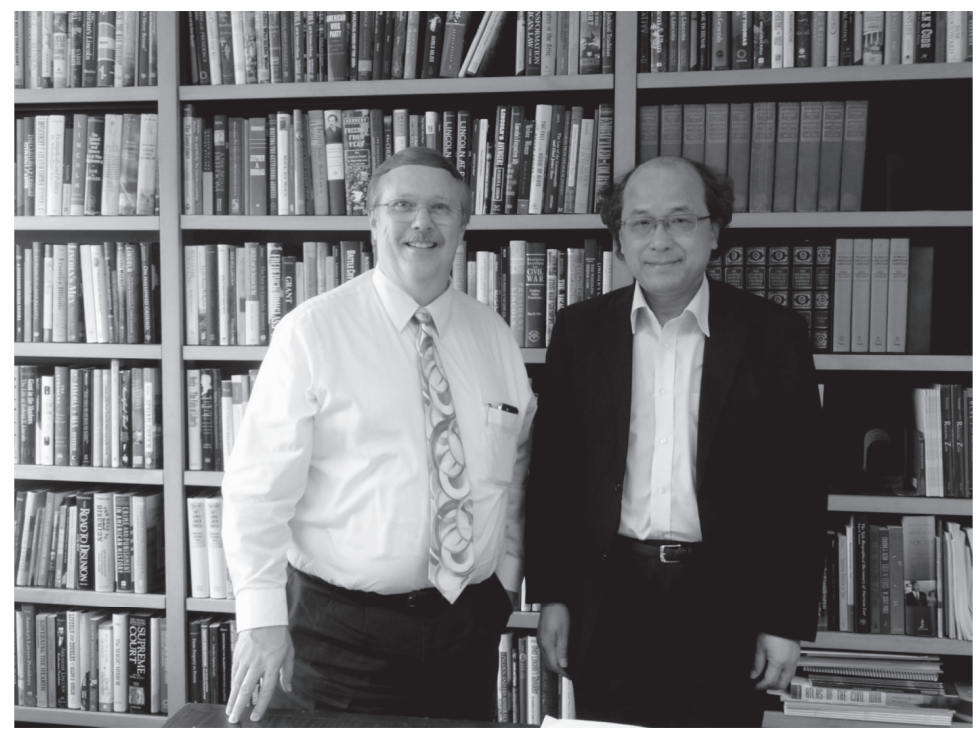

Daniel Stowell welcoms De-min Tao at his office 
ished the memory of His Excellency Abraham Lincoln to his countrymen, for the eminent services which he bestowed even to the sacrifice of his own life."

Abraham Lincoln: Citizen of the World also includes more than 150 letters of reflection on Abraham Lincoln's life and legacy from nations around the world, including several from Asia. The Japanese ambassador to the United States, officials from Taiwan, the Prime Minister of Thailand, and both the President of Myanmar and the ambassador to the United States from Myanmar offer their reflections on what Abraham Lincoln has meant to them personally and to their nations. General Prayut Chan-o-Cha, the Prime Minister of Thailand reflected that Lincoln's "unwavering commitment, courage, and sacrifice to bring about peace for his nation and prosperity for his people, continues to inspire not only the United States of America, but the entire world." His legacy "continues to guide the destiny of many countries, including Thailand's, as we are presently committed to our own reconciliation process that seeks to bring together all Thai people to build a stronger and sustainable democracy."

This juxtaposition of letters of condolence from 1865 with letters of reflection on Lincoln's legacy in 2015 offers a powerful demonstration of the global impact and importance of Abraham Lincoln's life, career, and legacy. Don H. Doyle, in his excellent The Cause of All Nations: An International History of the American Civil War (2014), argues persuasively that observers around the world viewed the conflict in the United States as a conflict between universal republican ideals of liberty and democracy and aristocratic beliefs in hierarchy and privilege. For the world, in Doyle's view, the Union that Abraham Lincoln struggled to preserve was indeed "the last best hope of earth."

The Internet allows researchers to explore a vast amount of material quickly and easily, but there is no substitute for the application of a human mind to the evidence left by previous generations to draw insights and wisdom from their experiences. Making authoritative source material about Abraham Lincoln's life and times available to researchers everywhere is the purpose of the Papers of Abraham Lincoln. We are pleased to make these materials available and to make them better and more complete. Abraham Lincoln is a global figure, and the Papers of Abraham Lincoln welcomes the collaboration of a worldwide body of researchers to comprehend the depth and breadth of his influence in his world and in ours. 


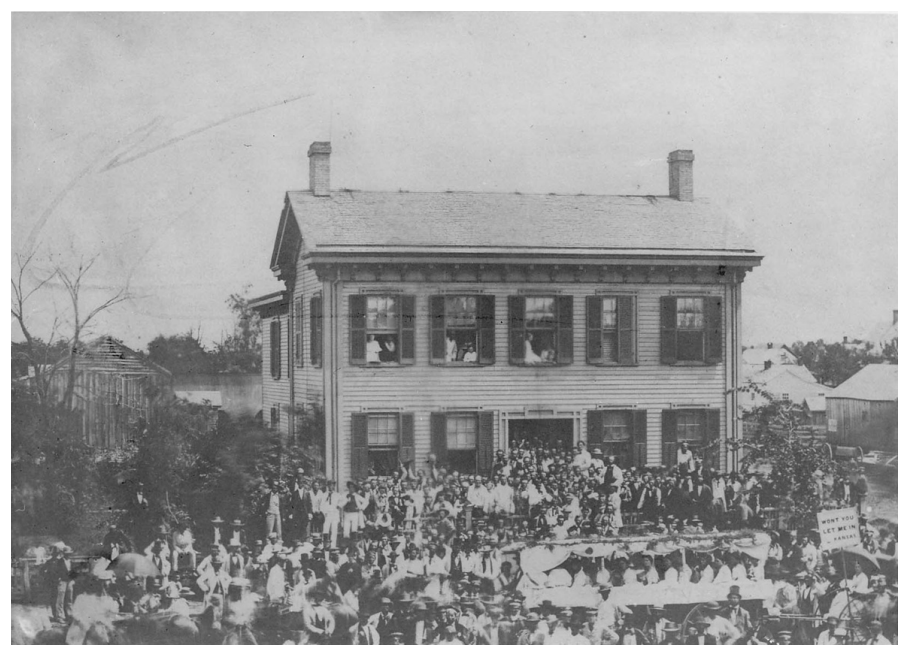

The Republican Rally at Lincoln Home, August 8, 1860

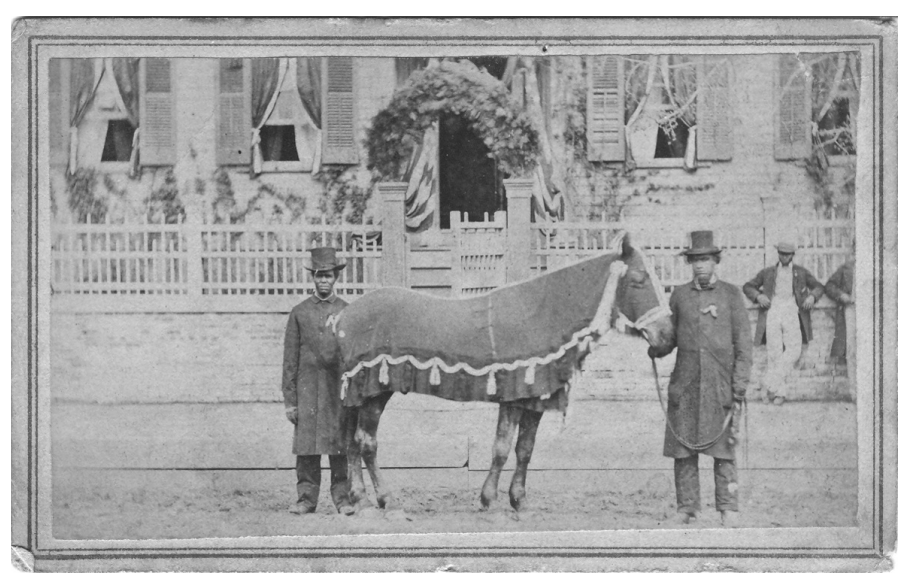

Rev. William C. Trevan (right); and Rev. Henry Brown (left) at Lincoln's Funeral, May 4, 1865

Courtesy of the Abraham Lincoln Presidential Library \& Museum, Springfield, Illinois 